\title{
TOPIC:
}

\section{APPLICATION OF GOOD AGRICULTURAL PRACTICES (GAP) BY THE BANANA FARMERS OF CHITWAN, NEPAL}

\author{
Arati Joshi $^{{ }^{*}}$, Dharmendra Kalauni ${ }^{\mathrm{a}}$, Ujjal Tiwari ${ }^{\mathrm{b}}$ \\ ${ }^{a}$ Faculty of Agriculture, Agriculture and Forestry University, Rampur, Chitwan, Nepal \\ ${ }^{\mathrm{b}}$ Department of Agri-Economics and Agri-business Management, Faculty of Agriculture, \\ Agriculture and Forestry University, Rampur, Chitwan, Nepal \\ *Corresponding author: arati.joshi.9638@gmail.com
}

Arati Joshi is an agriculture graduate from Agriculture and Forestry University. Her area of interest includes agricultural economics, extension, gender studies and environmental science. She is currently working as an Agriculture Instructor.

Dharmendra Kalauni is an agriculture graduate from Agriculture and Forestry University. His area of interest includes agricultural and applied economics and statistics. He is currently working as Agriculture Extension Officer.

Ujjal Tiwari is an assistant professor of Department of Agri-Economics and Agri-business Management, Agriculture and Forestry University.

\begin{abstract}
The study was conducted to identify the cultivation practices followed by the banana growers and compares it with the framework of Good Agricultural Practices as recommended by the World Banana Forum. Both qualitative and quantitative approach was used for data collection. The scheduled interview was carried out from 103 banana growers, two focused group discussion was carried out with the banana growers, and two key informant interview was carried out; one with the President of Banana Growers Association, Chitwan and another with Executive Director of Chamber of Commerce and Industry, Chitwan. The findings revealed that GAP related to soil management and fertilization (87.4\%) and harvesting and on-farm processing $(94.2 \%)$ is adopted at a low level. Only $36 \%$ of farmers apply an appropriate dose of chemical fertilizer, $28 \%$ follow crop rotation and $7.8 \%$ perform mulching/ intercropping. About $38 \%$ of the respondents do not have any source of irrigation. About $98 \%$ of the farmers do not perform any processing, cleaning, storing, and packaging of banana. Further, 55\% of farmers do not use appropriate personal protective equipment while applying pesticides. The results showed that there is low awareness regarding GAP among the banana farmers in the Chitwan district. Therefore, the conduction of awareness programs and training related to GAP is recommended. By far, no study has been carried out to analyze the good agricultural practices applied by banana growers in Nepal. This study identified the prevailing gap in farmer's practices and good agricultural practices.
\end{abstract}

Keyword: Energy; Faulty; Irrigation; Malbhog; Management

\section{INTRODUCTION}


After the green revolution, the usage of chemical fertilizer has significantly raised to increase crop production globally. Similarly, with the progress in science and technology, the usage of chemical pesticides for the control of disease, pest, and weed had increased. The wide application of chemical fertilizer and pesticide in the crop is making them unsafe to consume, creating a threat to consumers and the producers. There has been bitter evidence of rejection of Nepalese products from the European Union (THT, 2007). Further, it harms the soil, environment, and impedes the trading of agri-product.

The enforcement of Good Agriculture Practice (GAP) has greater relevance in recent days as it ensures safe crop production, facilitate regional trade through the implementation of common GAP standards in the region and ensure acceptability of fruits and vegetables in the international markets. It helps to produce quality goods with high yield that comply with the standards of national and international regulations. Implementation of GAP ensures environmentally friendly agricultural production, considering human health and welfare, improving the profitability and productivity of the farm. There are several examples of the increase in yield of agricultural produce by the implementation of GAP. Danquah et al. (2015) reported that the implementation of GAP increases maize yield by $25-27 \%$ and cowpea yield by $8-29 \%$ in Ghana. Also, the authors reported that the implementation of GAP increases the benefit-cost ratio of maize and cowpea by $36.1-72.8 \%$ and $11.1 \%-19.5 \%$ respectively. Dorji et al. (2016) reported that the adoption of GAP by farmers leads to increased yield and income. Bairagi, Mishra, and Giri (2018) reported that a 10-point increase in the adoption of the GAP-index increases farm income by $6.2 \%$ and decreases chemical fertilizer usage by $31 \%$ for paddy, tomato, lentil and ginger in Nepal.

As a member of the World Trade Organization (WTO), Nepal has adopted the Agreement on the Application of Sanitary and Phyto-sanitary Measures and the Agreement on Technical Barriers to Trade. In response to international food safety and quality concerns, to promote sustainable development and increase the export of agricultural produce, Government of Nepal, Ministry of Agriculture and Livestock Development (MOALD) has prepared NepalGAP (Nepal Good Agricultural Practice) Implementation Directives as the first step towards food safety and trade facilitation (MoAD, 2018). For any farm, that wants to receive recognition or certification of Good Agriculture Practice (GAP) has to apply for it in the respective accreditation institute, which in case of Nepal is Department of Food Technology and Quality Control (DFTQC) and then have to successively have to abide by the rules as mentioned in the NepalGAP Implementation Directive. Upon the successful accomplishment of the standards set by the certification body, the farm receives a certification of GAP (MoAD, 2018).

\subsection{GAP for banana}

Fruits are one of the most vulnerable commodities for transmission of the disease since they are consumed in raw form. Certification of fruit, ensuring its safety for consumption is quite important. In Nepal, the area under fruit has increased by $165 \%$ in year 2015/16 compared to the year 2000/01 (Pandey et al., 2017). Also, fruits are important for improving the economy of the nation. Among the crops, fruit contributes about 7\% to total Agriculture Gross Domestic Product (MoAD, 2016). Banana (Musa spp.) is one of the important fruit crops of Nepal which contributes about 24.3\% of total fruit production (MoAD, 2017). Banana is such a fruit whose demand is high throughout the year (Paudel \& Magar, 2016). 
Banana is one of the expanding cash crops in Nepal whose area has been increased by $78.5 \%$ in the last six years and production has increased by 103.3\% (MoAD, 2017, MoAC, 2011). The major banana growing districts are Morang, Jhapa, Chitwan, and Saptari. Among them, Chitwan is the third largest district in terms of area and fourth-largest in terms of production. In Chitwan, the area under banana cultivation is 1,733 ha (DADO, 2014/15) which has increased by $151.1 \%$ in the past six years (MoAD, 2017). Banana farming is flourishing mostly in eastern Chitwan and the living standards of farmers in these areas have also been improved due to this enterprise. Banana farming, which was started on 5.34 ha of land in eastern Chitwan in 2002, has now spread over 1733 ha (ICIMOD, 2015; DADO, 2014/15).

Banana is one of the major fruit crops of Nepal in terms of the potential growing area, production, and domestic consumption. However, the productivity of banana in Nepal is only 16 $\mathrm{Mt} / \mathrm{ha}(\mathrm{MoAD}, 2017)$ that is below the average world productivity i.e. $20 \mathrm{Mt} / \mathrm{ha}$ (FAO, 2019). Farmers are facing various hassles during production. The wind is one of the major risk factors of banana growers. Along with it, disease and pest have been causing serious damage to the fruit. Despite the continuous efforts of growers to control the disease and pest, the problem keeps causing nuisance since the planting to the fruiting period. Most of the farmers use sucker or rhizome as the planting materials (CADP, 2008), which passively carry the traces of pathogens from the mother plant. And the poor orchard management practices along with it provide a greater probability of disease and pest occurrence. Greater application of pesticides leads to residue occurrence in the fruit. In Nepal, pesticide residue in fruit crop is found to be 0.029187 $\mathrm{kg}$ ai/ha (Adhikari, 2017). The conventionally produced banana gives a low yield and is inferior in quality. Despite the increasing area under banana cultivation, productivity remains the same because of the lack of knowledge about the good agricultural practices among the farmers, and it is making the banana enterprise less profitable. To reduce the existing yield gap, banana farmers must adopt good agricultural practices. Joshi, Kalauni, and Tiwari (2019) reported that only $28.2 \%$ of the Banana farmers of Chitwan district were aware of GAP for banana. However, no study has been carried out to analyze the good agricultural practices applied by banana growers. This study will identify the prevailing gap in farmer's practices and good agricultural practices. Awareness and knowledge of new technologies is the first step toward its adoption (Roger, 1995). Therefore, this study assessed the awareness of GAP among banana farmers.

\section{METHODOLOGY}

The research was conducted in the command area of the PMAMP PIU Banana Zone, Chitwan. The study area was Kalika Municipality (Ward No. 1 to 8), Ratnanagar Municipality (all wards), Khaireni Municipality (all wards) and Bharatpur Metropolitan City (Ward no. 1). A list of banana growing farmers provided by the Banana zone, PMAMP Chitwan was used to randomly select the respondent. The scheduled interview was carried out with 103 banana growers, selecting 10\% farmers from each area i.e. 10 from Bharatpur Metropolitan City, 10 from Khaireni Municipality, 36 from Ratnanagar Municipality and 47 from Kalika Municipality. Key informant interviews (KII) and focus group discussion (FGD) were also carried out to triangulate data and information obtained from schedule interview and to obtain additional qualitative information.

The secondary data related to banana production was obtained from different institutes and organizations such as Agribusiness Promotion and Marketing Development Directorate, Ministry of Agriculture and Livestock Development, Central Bureau of Statistics, Agriculture Learning 
Center, Chitwan, Fruit Development Directorate, Food, and Agriculture Organization, etc. Both the primary and secondary information collected from the field survey and other methods was coded and tabulated on Statistical Package for the Social Sciences (SPSS). The analysis was done through SPSS, Stata and MS- Excel.

The farmer's perception toward GAP was analyzed using different variables. The perception was analyzed on a scale of strongly agree, agree, neither agree nor disagree, disagree and strongly disagree. Perceptions toward GAP were analyzed using an index of agreement. The frequency of agreement was calculated by the summation of the frequency of response of scale as strongly agree and agree. And the frequency of disagreement was calculated by the summation of the frequency of response of the scale: neither agree nor disagree, disagree and strongly disagree. Index of the agreement was calculated by using the following formula:

Index of agreement $=($ Frequency of agreement - Frequency of disagreement $) / \mathrm{n}$

Where, $\mathrm{n}=$ total sample size.

When the value of the index of the agreement is greater than 0.5 , the variable is considered to have a positive perception, whereas when the adoption index is less than 0.5 , the variable is considered to have a negative perception or attitude.

A GAP framework for banana made by World Banana Forum was used as a standard for evaluating the extent of GAP practices followed by banana growers. Descriptive statistics were used to evaluate the extent of application in percentages. The extent of the GAP application was analyzed under a different category as mentioned by World Banana Forum which is as: Soil Management and Fertilization, Water Stewardship, Crop Production, Crop Protection, Waste, and Energy Management, Harvesting and Farm processing and Workers healthy and safety.

\section{FINDINGS}

\subsection{Farm Size}

The mean banana cultivated land of the study area was $4.1390( \pm 6.6364)$ ha, of which average $0.4629( \pm 0.4484)$ ha area of own land is used by the banana farmers for cultivating banana. Farmers were found to use 0-2 ha of their land for cultivating banana. Most of the farmers cultivated banana only and only a few of them grow vegetables and cereals. About $71 \%$ of farmers took land in the lease for cultivating banana. Average of $3.2231( \pm 6.7642)$ ha of land was taken in the lease for cultivating banana. Most of the area about $57.5 \%$ of the area does not have the source of irrigation. Average $2.3830( \pm 5.9447)$ ha area of banana land was found to be non-irrigated and only $1.7560( \pm 2.6723)$ ha area was irrigated. The detail of land use under banana farming is shown in Table 1.

Shrestha et al. (2018) reported that the average landholding of banana farmers of Thimura, Ramnagar, Padampur, Ratnagar and Jagatpur area was 1.96 ha. The authors reported the average banana irrigated area to be 0.22 ha and an average banana unirrigated area to be 0.14 ha.

Similarly, Ghimire, Koirala, Devkota, and Basnet (2019) reported that the average area under banana farming in Ratnanagar and Khaireni municipality was 1.92 ha. The area under banana cultivation in our study is found greater than the past studies. It might be because of the different 
study areas and greater study area coverage in our case (i.e. Kalika Municipality, Ratnanagar Municipality, Khaireni Municipality, and Bharatpur Metropolitan City).

\subsection{Propagating material used by banana growers}

The greater number of farmers used sucker propagated material (95.1\%) than tissue culture $(1.9 \%)$ and only $2.9 \%$ used both of them in their orchard (Figure 1). Because of the easy availability of sucker and cheap price, farmers mostly use it. Similarly, CADP (2008) reported that farmers of Morang and Sunsari also used sucker as propagating material to a higher extent. However, due to an increasing infestation of disease and pests, some farmers used tissue culture plantlets.

\subsection{Banana variety used by farmers}

Among the total respondents, $95.1 \%$ have planted local variety Malbhog, $3.9 \%$ planted the variety Grand Nain (G-9) and 1\% planted variety William Hybrid (Figure 2). Farmers have received the tissue culture saplings of variety William Hybrid from DADO during the OVOP program. Variety G-9 was imported by farmers from the tissue culture laboratory of Nepaljung and some from Kathmandu. Few farmers explained that the tissue culture plantlet they received was not of good quality. It was a mix of Malbhog and G-9. Farmers have to face a heavy loss due to the poor quality of tissue culture sapling because such a plant got severely infested with disease and pest in the later stage. CADP (2008) reported that progressive farmers prefer tissue culture saplings, but unavailability of it locally in Sunsari is the major problem. A similar problem was observed in the Kailali district (NHPC, 2017). Therefore, most of the farmers have shifted to the use of local variety Malbhog. In our study, the respondent gave a higher preference to local variety, Malbhog for its high price and demand, drought-tolerant ability and high keeping quality.

\subsection{Perception of farmers toward GAP}

The perception of respondents towards GAP is analyzed using an index of agreement. The value of an index of agreement may vary from - 1 to 1 , with values greater than 0.5 indicating positive responses. The perception of respondents toward GAP was found positive except for the statement; GAP reduces the input cost of production. About $61.2 \%$ of the respondent (index= 0.22 ) were found to disagree with this statement. While the entire respondent agreed to the fact that, GAP is a sustainable practice, GAP produced crop has higher quality, and GAP reduces farmers' exposure to health hazards. About $83.3 \%$ of the respondents (index $=0.66$ ) agreed to the statement that GAP is a time-consuming practice. Respondent stated that GAP requires high care and time for management. Similarly, $89 \%$ of the respondent (index $=0.77$ ) agreed that GAP reduces all forms of pollution. About $83.3 \%$ of the respondent (index $=0.67$ ) agreed that GAP increases the farmer's income. The perception of respondents regarding the other statement is shown in Table 2.

\subsection{GAP application by farmers}

\subsubsection{Soil management and fertilization}

Only $35.9 \%$ of the respondents applied the appropriate amount of fertilizer to the banana crop (Figure 3). Most of the farmers applied the organic manure during land preparation, and the chemical fertilizers like urea, potash, and DAP were applied once the plant gets established, i.e. 
after one month of planting. Only a few farmers top-dress the fertilizers in a recommended interval, while most of them only apply the fertilizer once. Only $32.5 \%-50 \%$ of farmers applied the recommended dose of fertilizer in banana in India (Hassan, 2016). About 28\% of the respondent followed crop rotation, while most of the farmers replaced the field with another variety of banana or abandon the field taken on lease. Tiwari et al. (2006) reported that only $12 \%$ of banana growers of Chitwan follow crop rotation. Only $7.8 \%$ of the farmers planted a cover crop or intercrop between the banana inter-rows. Respondents plant vegetables like- cauliflower, bean, and others during the early stage of the plant. Hassan (2016) reported that only 2.5-5\% of farmers have practiced intercropping in banana in the early stage in India.

\subsubsection{Water stewardship}

About $91 \%$ of the respondents had a drainage facility in the banana orchard and there was no water logging problem (Figure 4). Similarly, 92.2\% of the respondents reported that they used organic matter in the soil while planting banana. Organic matter helps to hold moisture in the soil. About $37.9 \%$ of the respondents do not have any source of irrigation in their orchard and depend on the rainfall for irrigating their fields. Shrestha and Giri (2012) reported that 37\% of farmers of Kailali district faced irrigation problems, and Poudel (2011) reported scarcity of irrigation as the major problem faced by banana growers in Nawalparasi. About $62.1 \%$ respondent provided clean and pure water to banana plant that is free from the harmful microorganism. Most of the farmers irrigate their fields by pumping groundwater and some of them through the canal. About $81.5 \%$ of the respondents do not supply irrigation water regularly. Only $2.5 \%$ of the farmers have adopted water-saving practices like drip irrigation.

\subsubsection{Crop production}

About $48.5 \%$ of the respondents have performed the soil test of their banana orchards (Figure 5). They have performed the soil test during the roving soil test program organized in their area. About $26.2 \%$ of the respondents do not apply the fertilizer in a recommended interval. Gautam and Tiwari (2007) reported that applying a higher dose of nitrogen at a time leads to nitrification and leaching, therefore, nitrogen should be applied two months, four months and six months after sucker planting. Similarly, potash should be applied during sucker planting and bunch formation. Only 33\% of the potato farmers of Sri Lanka have performed the soil test once in two years and only $26 \%$ of farmers apply the recommended fertilizer (Senanayake \& Rathnayaka, 2015). Almost all of the farmers except 5.8\% were found to recycle the residues (i.e. pseudostem, leaves) of the banana crop as organic manure. About $73.7 \%$ of the farmers do not to safely regulate the equipment used in banana farming viz. sickle, shovel and other. Most of them clean the equipment only by water while some of them practice solar drying of the equipment after use, for disinfection.

\subsubsection{Crop protection}

About $74.8 \%$ of the farmers applied a chemical pesticide in their orchard based on the weather condition (Figure 6), while others used to mix stickers in the chemical pesticide and apply it in the field irrespective of the weather condition. About $95 \%$ of the respondents made a regular survey in their field and implement immediate crop protection measures in case of pest and disease outbreak. However, only $4.5 \%$ of the respondents were found to use the disease-resistant variety of banana plant viz. William Hybrid and Grand Nain (G-9). Only 5.8\% of the farmers adopted mechanical weed control and only $3.9 \%$ of respondents have adopted IPM measure of 
disease and pest control in their orchard. About $87.4 \%$ of the respondents mobilized the experienced worker for handling and application of pesticides. About $35 \%$ of the respondents do not know registered or banned pesticides. According to THT (2018), farmers of Dhankuta are using banned pesticides like- monocrotophos, phorate, and quintalphos. Only $44.7 \%$ of the respondents used all the personal protective equipment (PPE) while spraying chemical pesticides, while others used only a few of the personal protective equipment (e.g. mask only, mask and boot only). Rijal et al. (2018) reported that $34 \%$ of farmers use masks only and $14 \%$ of farmers do not use PPE at all while spraying the pesticide. About $26.3 \%$ of the respondents safely maintain their equipment and $39.8 \%$ of respondent keep the record of the use of pesticides.

\subsubsection{Harvesting and on-farm processing and storage}

About $97.1 \%$ of the respondents considered the pre-harvest interval (Figure 7). Usually, farmers do not apply chemical pesticides after finger formation in the bunch. Only $1.9 \%$ of the farmers in the study area cleaned the harvested banana and safely stores it in a clean and hygienic condition. Similarly, negligible farmers were found to process the banana and perform packaging before shipment. Farmers of the study area, sell the banana on the orchard itself. Usually, the trader (mostly from Chitwan, Kathmandu, Pokhara, Butwal) come to the farm, harvest the quantity of banana required, load it in the vehicle (usually bolero) and transport it to the destination. NHPC (2017) reported that while transporting banana no packaging materials are used except covering by the banana leaves in Kailaki district. This may cause physical injury to the banana fruits. The post-harvest loss in a banana is about $10-15 \%$, which is greater than mango, citrus, and apple. Noncompliance with the post-harvest practices may lead to the infestation of the pathogenic micro-organism. Khadka et al. (2017) reported that the adoption of post-harvest handling practices in tomato, reduces the aerobic bacterial count, coliform bacterial count, mold growth and increases the self-life.

\subsubsection{Energy and waste management}

The entire respondent safely disposes of the farm wastes like- nutrients, empty pesticide containers, tanks, and others. Most of them send such waste with the garbage collecting vehicle of Municipality/ Metropolitan City. Some of them bury such waste in the pit while some burn it. The respondent took care of the fact that such waste must not affect the children or animals. About $85.4 \%$ of the respondent securely stored fertilizer in a safe place (Figure 8). About $43.2 \%$ of the farmers reported that they have been trying to minimize the non-recyclable waste in the farm and recycle the organic and inorganic waste. Only $17.5 \%$ of the farmers recorded the total energy consumption on the farm, while none of the farmers have adopted alternative energy sources and establish emergency procedures to limit the risk of pollution. CADP (2008) reported that in Morang and Sunsari, a high share of costs incurred in banana cultivation is from irrigation, which is done by diesel-powered pumping set. The dependency of banana cultivation on such non-renewable fossil fuel does not primarily increase the cost of production but also affects the environment. Some alternatives might be rainwater harvesting, use of solar energy for water pumping, multiple uses of water and drip and sprinkler irrigation technology.

\subsubsection{Human welfare and health and safety}

About $88 \%$ of the respondents have trained the worker to safely use the tools used in the banana farm (Figure 9). Similarly, about $82 \%$ of the respondents have provided decent wages to the 
workers based on the intensity of work. The entire respondent reported to provide an acceptable working hour for the workers with the proper rest time.

\subsection{Total GAP practiced by the respondent}

Based on the mean of GAP application (i.e. 0.4), the category of GAP practiced is classified as none applied (0), low level of application (0.1-0.3), medium level of application (0.4-0.7) and high level of application (0.8-1) as shown in Figure 10. About $44 \%$ of the good agricultural practices of soil management and fertilization are not practiced by the respondent. Low-level GAP was practiced in harvesting and on-farm processing (94\%), energy and waste management (55\%), and soil management and fertilization (44\%). Medium level of the application was for crop protection (80\%) followed by water stewardship (78\%) and crop production (74\%). The highest level of the application was for elements: human welfare and health and safety (79\%), followed by water stewardship (22\%) and, crop production $(11 \%)$.

\section{CONCLUSION}

The majority of farmers in the Chitwan district take land in the lease for banana farming. However, most of the banana cultivated area was non-irrigated and therefore, farmers mostly prefer local drought-tolerant variety Malbhog. Farmers of the study area practice poor soil management, harvesting, and post-harvest handling and energy management. To improve the yield and quality of banana in the future, attention should be given to these practices. Good agricultural practice as reported by different researches is a one-stop solution to enhance the production, productivity, and quality of the Banana. Thus to revitalize the Banana subsector, we need to educate farmers about good agricultural practices.

\section{CONFLICT OF INTEREST}

Authors declare no potential conflict of interest.

\section{REFERENCES}

Adhikari, P. R. (2017 ). An Overview of Pesticide Management in Nepal. The Journal of Agriculture and Environment Vol:18, , 95-105.

Bairagi, S., Mishra, A. K., \& Giri, A. (2018). Good agricultural practices, farm performance, and input usage by smallholders: Empirical evidence from Nepal Agribusiness, 1-21.

CADP. (2008). Product Chain Study: Banana. Biratnagar: Commercial Agriculture Development Project, Ministry of Agriculture and Cooperatives.

DADO. (2014/15). Krishi Upaj Sankalan/ Bajar Kendraharuko Profile. Bharatpur: District Agriculture Development Office.

Danquah, E. O., Ennin, S., Frimpong, F., Oteng-Darko, P., Yeboah, S., \& Osei-Adu, J. (2015). Adoption of good agricultural practices for sustainable maize and cowpea production: The role of enabling policy. World Research Journal of Agricultural Sciences 2(2), 2838. 
Dorji, K., Lakey, L., Chophel, S., Dorji, S. D., \& Tamang, B. (2016). Adoption of improved citrus orchard management practices: a micro study from Drujegang growers, Dagana, Bhutan. Agriculture \& Food Security 5:3, 1-8.

FAO. (2019). Banana facts and figures. Retrieved 2019, from Food and Agriculture Organization of the United States: http://www.fao.org/economic/est/estcommodities/bananas/bananafacts/en/\#.XFaUBlUzbIU

Gautam, D. M., \& Tiwari, S. (2007). Byabasayik Kera Kheti. Bhairahawa: Institute of Agriculture and Animal Science.

Ghimire, S., Koirala, B., Devkota, S., \& Basnet, G. (2019). Economic analysis of commercial banana cultivation and supply chain analysis in Chitwan, Nepal. Journal of Pharmacognosy and Phytochemistry, 190-195.

Hassan, S. N. (2016). A Study on Technological Gap in Banana Cultivation Technologies in Southern District of Tamil Nadu. International Journal of Scientific and Research Publication 6(7), 388-394. https://www.scribd.com/document/108033615/BananaSupply-Chain-CADP

ICIMOD. (2015) Expanding Commercial Banana Production. International Center for Integrated Mountain Development. Kathmandu, Nepal.

Joshi, A., Kalauni, D., \& Tiwari, U. (2019). Determinants of awareness of good agricultural practices (GAP) among Banana growers in Chitwan, Nepal Journal of Agriculture and Food Research Vol 1. doi: 10.1016/j.jafr.2019.100010.

Khadka, R. B., Marasini, M., Rawal, R., Gautam, D. M., \& Acedo, A. L. (2017). Effects of Variety and Postharvest Handling Practices on Microbial Population at Different Stages of the Value Chain of Fresh Tomato (Solanum lycopersicum) in Western Terai of Nepal. BioMed Research International

MoAC. (2011). Statistical Information on Nepalese Agriculture 2010/2011 (2068/069). Kathmandu : Ministry of Agriculture and Co-operatives, Agri-Business Promotion and Statistics Division.

MoAD. (2016). Statistical Information on Nepalese Agriculture 2015/2016 (2072/73).. Singhdurbar, Kathmandu,Nepal: Agri Statistics Section,Agribusiness Promotion and Statistics Division, Ministry of Agriculture Development.

MoAD. (2017). Statistical Information on Nepalese Agriculture 2016/17 (2073/74). Kathmandu: Ministry of Agricultural and Livestock Development.

MoAD. (2018). Nepal Asal Krishi Abyash Karwanayan Nirdesika. Kathmandu: Ministry of Agriculture and Livestock Development.

NHPC, N. H. (2017). Nepal : Fruit Development Project. Lalitpur: Fruit Development Directorate. 
Pandey, G., Basnet, S., Pant, B., Bhattarai, K., Gyawali, B., \& Tiwari, A. (2017). An Analysis of Vegetables and Fruits Production Scenario in Nepal. Asian Research Journal of Agriculture 6(3), 1-10.

Paudel, U., \& Magar, S. B. (2016). Study on Fruit Marketing Situation in Kathmandu Valley. In B. P. Rajbhandari, K. B. Shrestha, U. M. Singh, \& B. P. Bhattarai (Eds), HICAST Research Abstract (p. 21). Kathmandu: Himalayan College of Agricultural Sciences and Technology.

Poudel, T. (2011). Economics of production and marketing of banana in Nawalparasi district, Nepal. Bharatpur: Agriculture and Forestry University.

Rijal, J. P., Regmi, R., Ghimire, R., Puri, K. D., Gyawaly, S., \& Poudel, S. (2018). Farmers' Knowledge on Pesticide Safety and Pest Management Practices: A Case Study of Vegetable Growers in Chitwan, Nepal. Agriculture 8(16)

Rogers, E. (1995). Diffusion of innovations. New York, NY: The Free Press.

Senanayake, S., \& Rathnayaka, R. (2015). Analysis of factors affecting for adoption of good agricultural practices in potato cultivation in Badulla district, Sri Lanka. Agrieast 10, 1-5.

Shrestha, A., Sapkota, B., Regmi, R., \& Dhungana, S. M. (2018). Economics of production and marketing of banana in Chitwan district, Nepal. Azarian Journal of Agriculture 5(1), 12 19.

Shrestha, G., \& Giri, S. (2012). Socio-economic Condition of Banana Growers and Banana Production Technology in Kailali District. Nepalese Horticulture, 35-40.

THT. (2007, July 21). Pesticide-monitoring plan. Retrieved 2019, from The Himalayan Times: https://thehimalayantimes.com/kathmandu/pesticide-monitoring-plan/

THT. (2018, October 24). Farmers using banned pesticides in Dhankuta. Retrieved 2019, from The Himalayan Times: https://thehimalayantimes.com/nepal/farmers-using-bannedpesticides-in-dhankutal

Tiwari, S., Thapa, R. B., Gautam, D. M., \& Shrestha, S. K. (2006). Survey of Banana Stem Weevil, Odoiporus Longicollis (Oliv.) (Coleoptera : Curculionidae) in Nepal. Journal of Institute of Agriculture and Animal Science 27, 127-131. 
Table 1. Land use under banana farming

Total

Irrigated land Non-irrigated cultivated

\begin{tabular}{lrrrrr} 
& Own (ha) Leased in (ha) & (ha) & land (ha) & (ha) \\
\hline Mean & 0.46 & 3.70 & 1.75 & 2.38 & 4.13 \\
Std. Deviation & 0.44 & 6.70 & 2.67 & 5.94 & 6.63 \\
Minimum & 0.00 & 0.00 & 0.00 & 0.00 & 0.10 \\
Maximum & 2.02 & 47.29 & 13.90 & 47.29 & 47.29 \\
\hline
\end{tabular}

Source: Field survey, 2019

Table 2. Perception of respondents toward GAP

\begin{tabular}{|c|c|c|c|c|c|c|}
\hline Statement & $\begin{array}{l}\text { Strongly } \\
\text { Agree } \\
(\%)\end{array}$ & $\begin{array}{l}\text { Agree } \\
(\%)\end{array}$ & $\begin{array}{l}\text { Neutral } \\
(\%)\end{array}$ & $\begin{array}{l}\text { Disagree } \\
(\%)\end{array}$ & $\begin{array}{l}\text { Strongly } \\
\text { Disagree } \\
(\%)\end{array}$ & $\begin{array}{l}\text { Index of } \\
\text { agreement }\end{array}$ \\
\hline $\begin{array}{l}\text { GAP is a sustainable } \\
\text { practice for future }\end{array}$ & 83.3 & 16.7 & 0.0 & 0.0 & 0.0 & 1 \\
\hline $\begin{array}{l}\text { GAP produced banana } \\
\text { has nicer appearance } \\
\text { and quality }\end{array}$ & 94.4 & 5.6 & 0.0 & 0.0 & 0.0 & 1 \\
\hline $\begin{array}{l}\text { GAP is a time } \\
\text { consuming practice }\end{array}$ & 72.2 & 11.1 & 0.0 & 16.7 & 0.0 & 0.66 \\
\hline $\begin{array}{l}\text { GAP reduces all form } \\
\text { of pollution }\end{array}$ & 77.8 & 11.1 & 11.1 & 0 & 0.0 & 0.77 \\
\hline $\begin{array}{l}\text { GAP reduces cost of } \\
\text { production }\end{array}$ & 33.3 & 5.6 & 0.0 & 55.6 & 5.6 & -0.22 \\
\hline $\begin{array}{l}\text { GAP increases farmer's } \\
\text { income }\end{array}$ & 61.1 & 22.2 & 11.1 & 5.1 & 0.0 & 0.67 \\
\hline $\begin{array}{l}\text { GAP reduces farmer's } \\
\text { exposure to health } \\
\text { hazards }\end{array}$ & 72.2 & 27.8 & 0.0 & 0.0 & 0.0 & 1 \\
\hline
\end{tabular}

Source: Field survey, 2019 
bioRxiv preprint doi: https://doi.org/10.1101/2020.06.12.148551. this version posted June 14, 2020. The copyright holder for this preprint (which was not certified by peer review) is the author/funder, who has granted bioRxiv a license to display the preprint in perpetuity. It is made available under aCC-BY 4.0 International license.

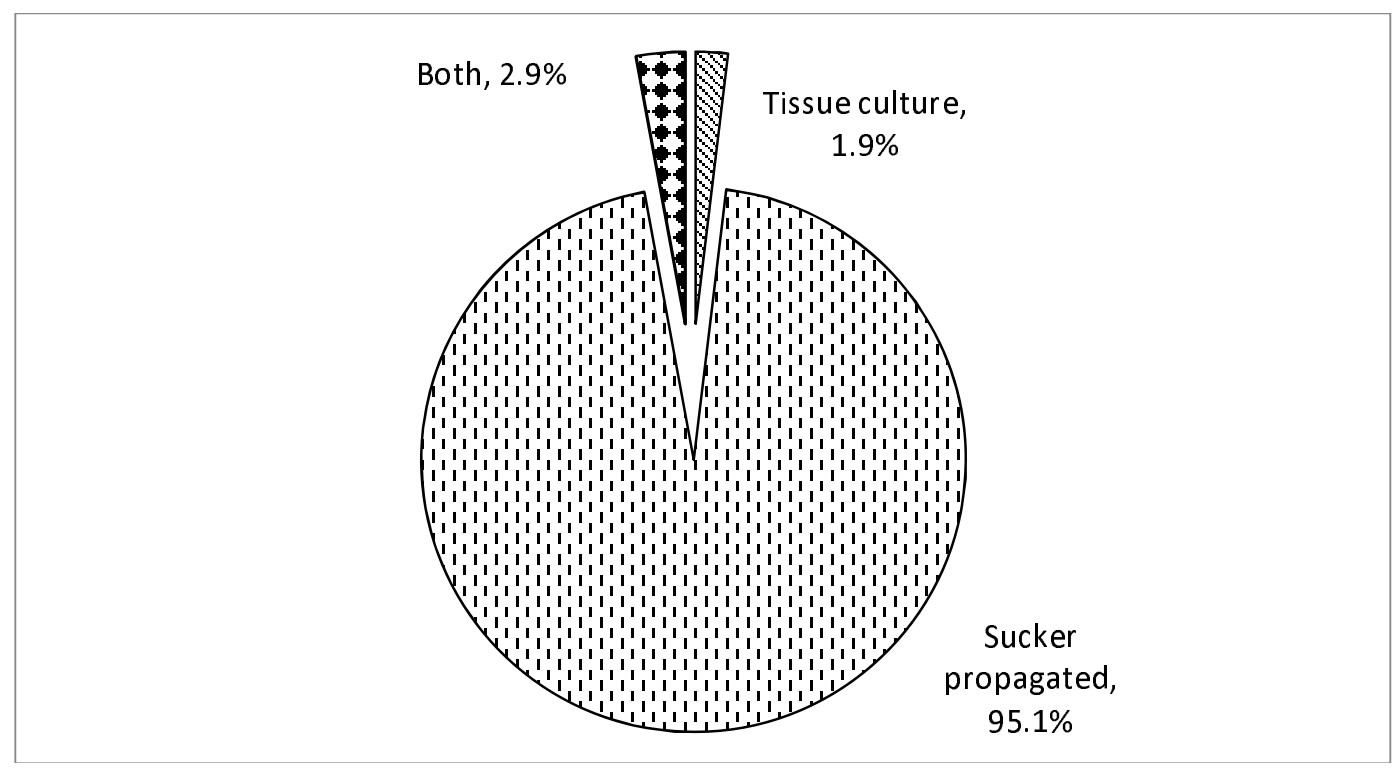

Figure 1. Propagating material used by the respondents

Source: Field survey, 2019

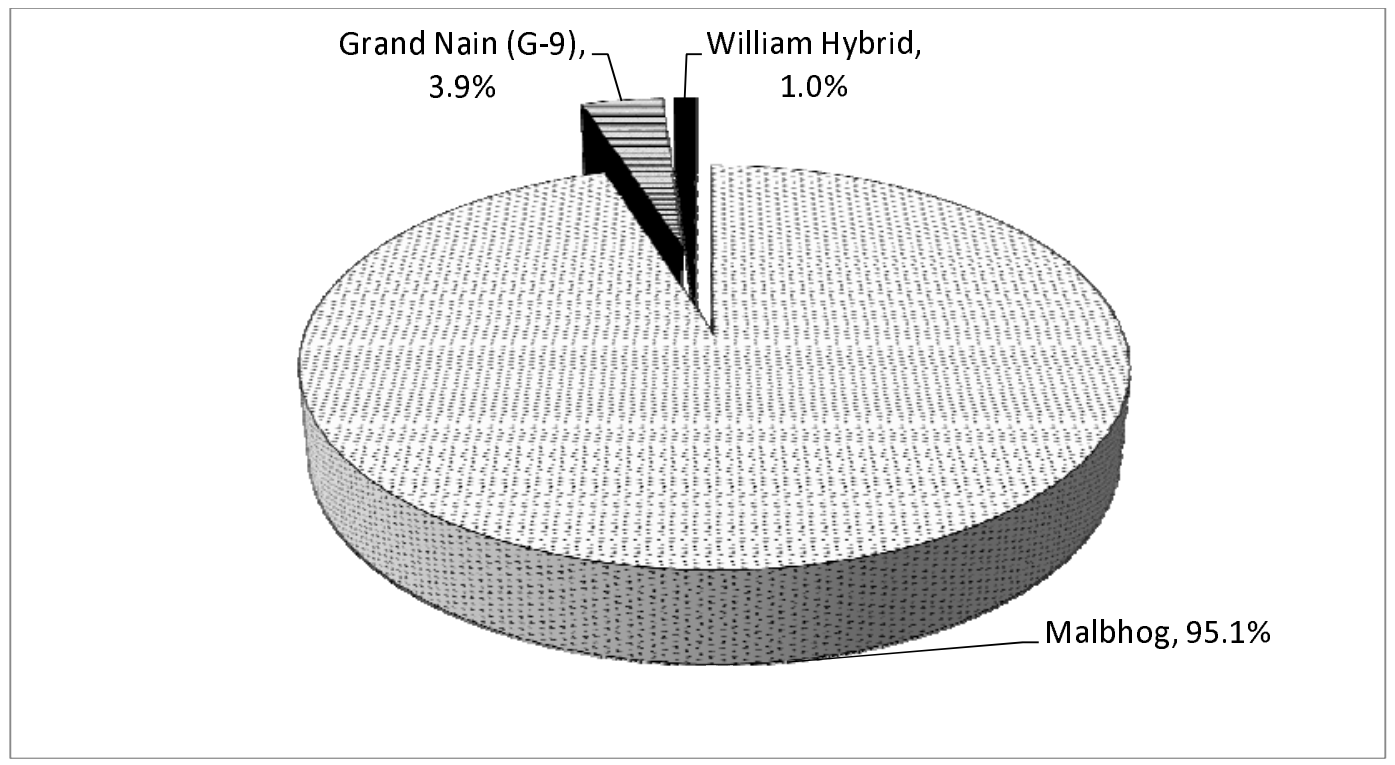

Figure 2. Banana variety used by growers

Source: Field survey, 2019 


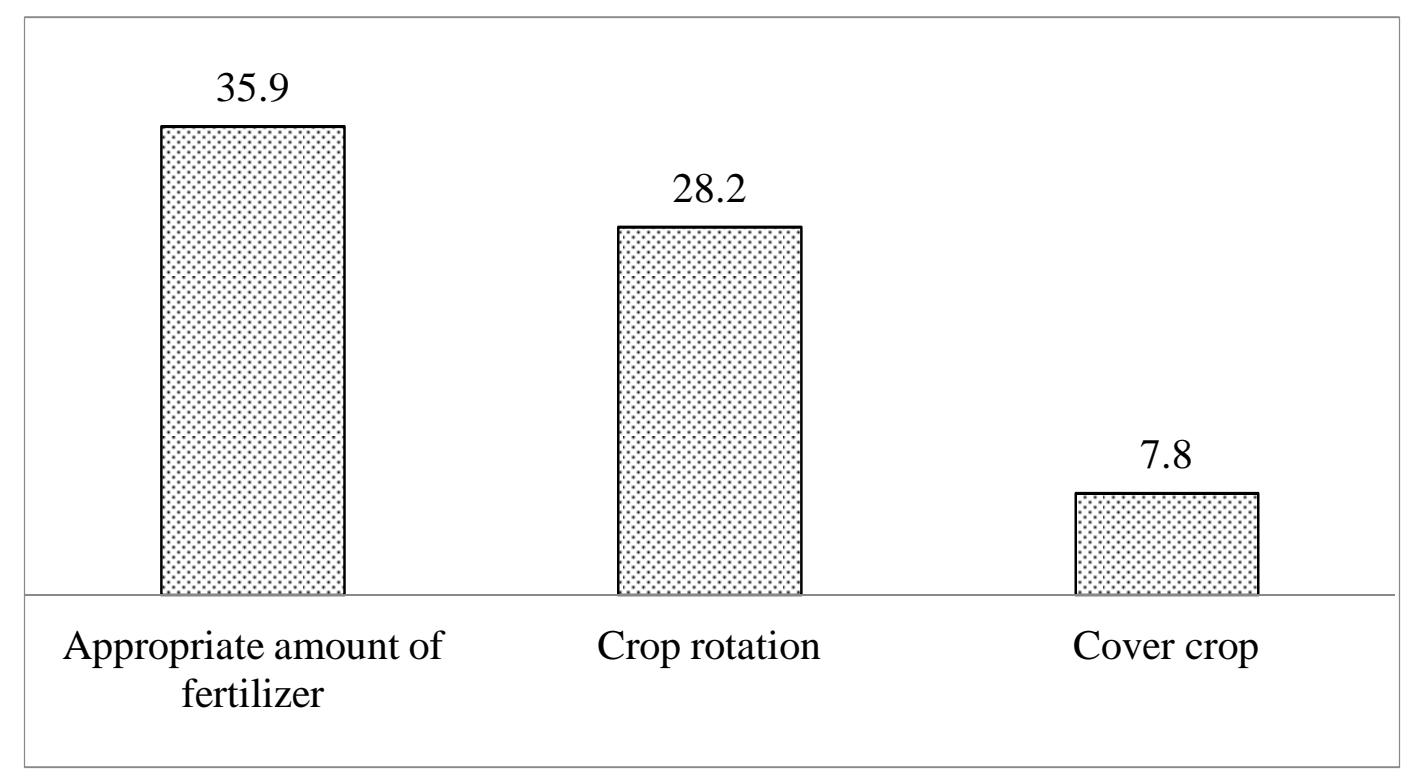

Figure 3. Percentage of respondent farmers adhering to GAP related to soil management and fertilization

Source: Field survey, 2019

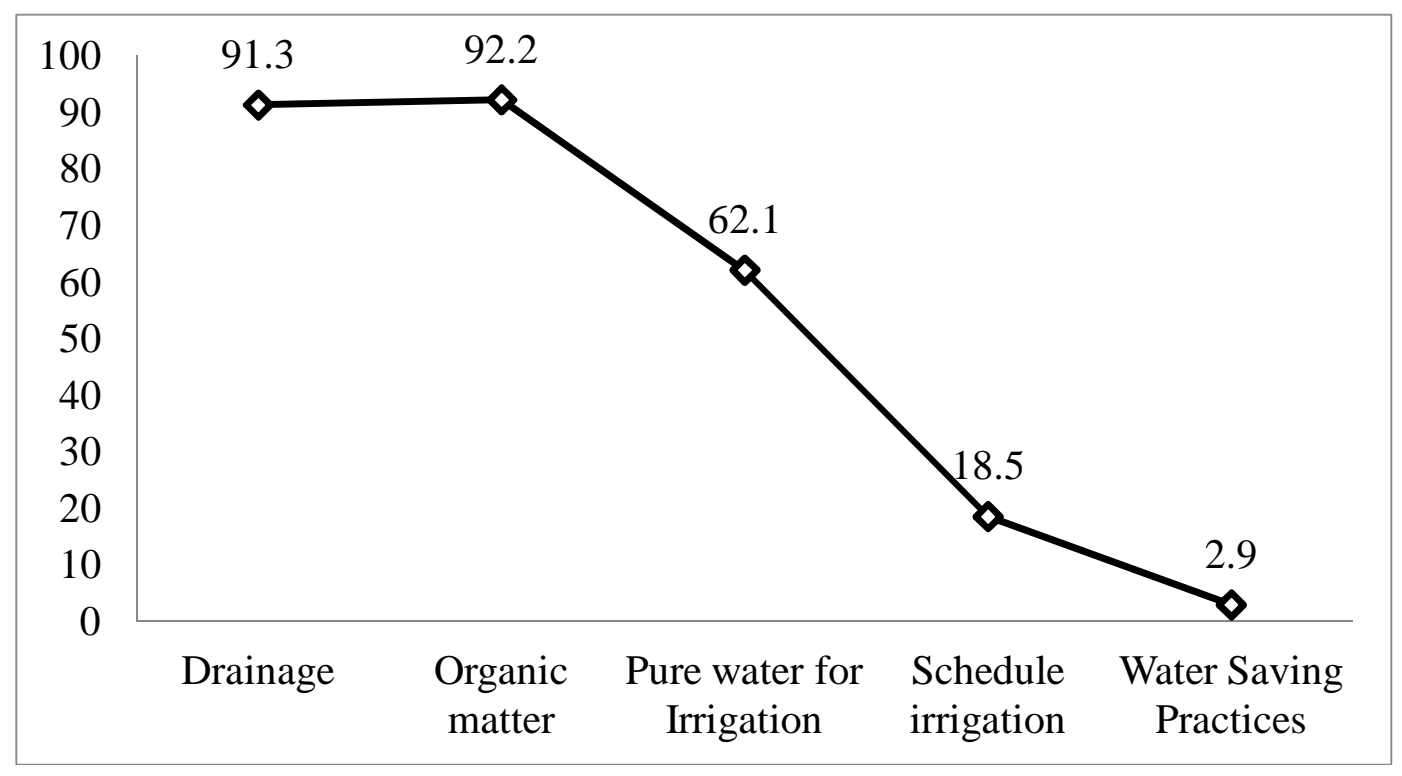

Figure 4. Percentage of farmers adhering to GAP related to water stewardship

Source: Field survey, 2019 


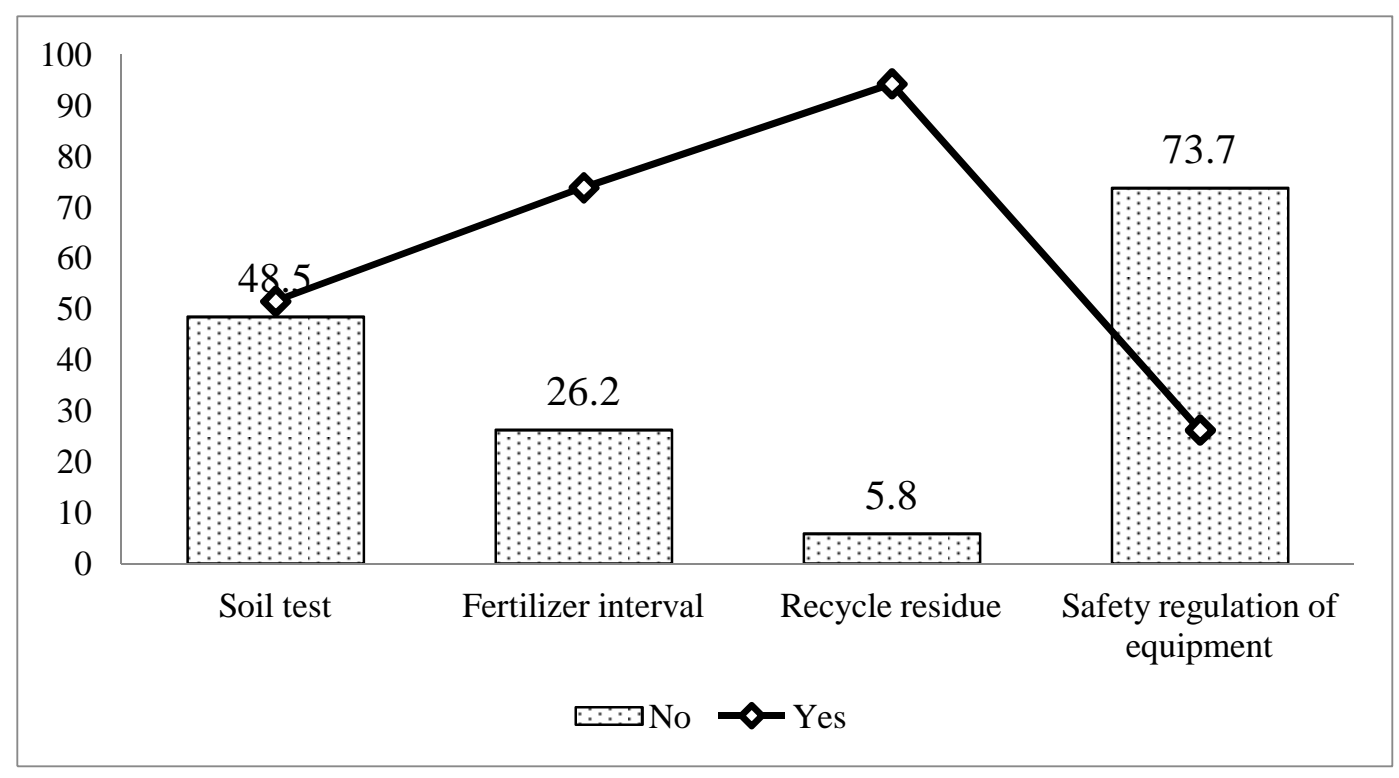

Figure 5. Percentage of farmers adhering to GAP related to crop production Source: Field survey, 2019

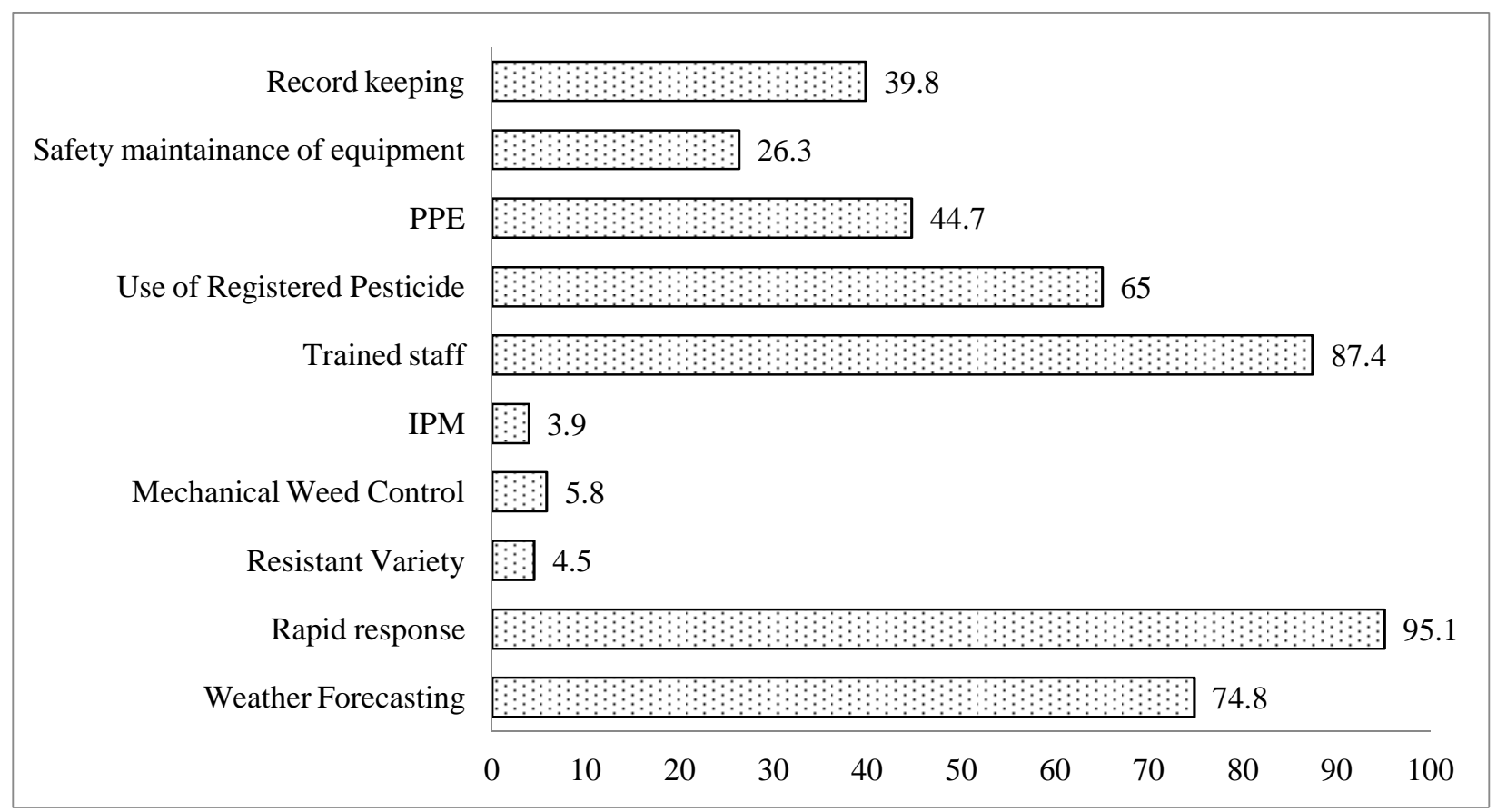

Figure 6. Percentage of farmers adhering to GAP related to crop protection 


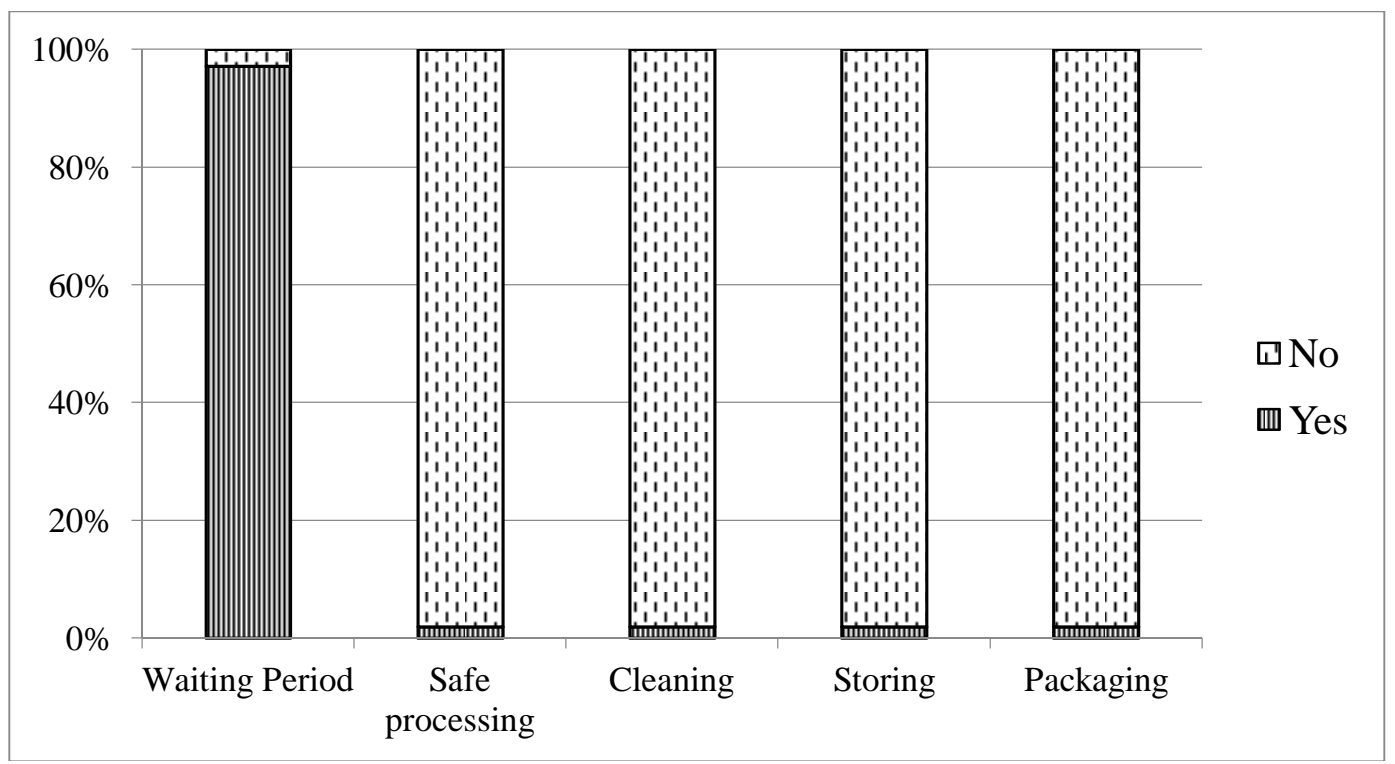

Figure 7. Percentage of farmers adhering to GAP related to harvesting and on farm processing and storage

Source: Field survey, 2019

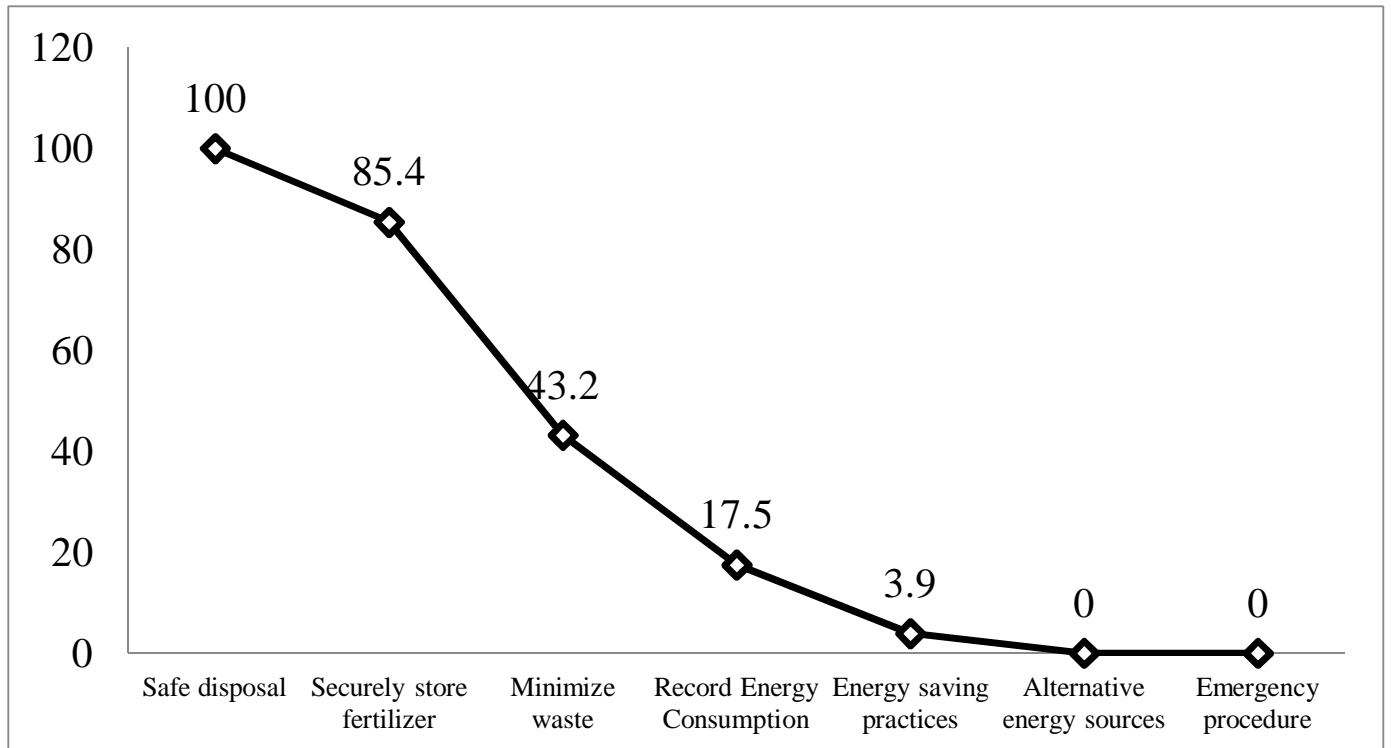

Figure 8. Percentage of farmers adhering to GAP related to energy and waste management

Source: Field survey, 2019 


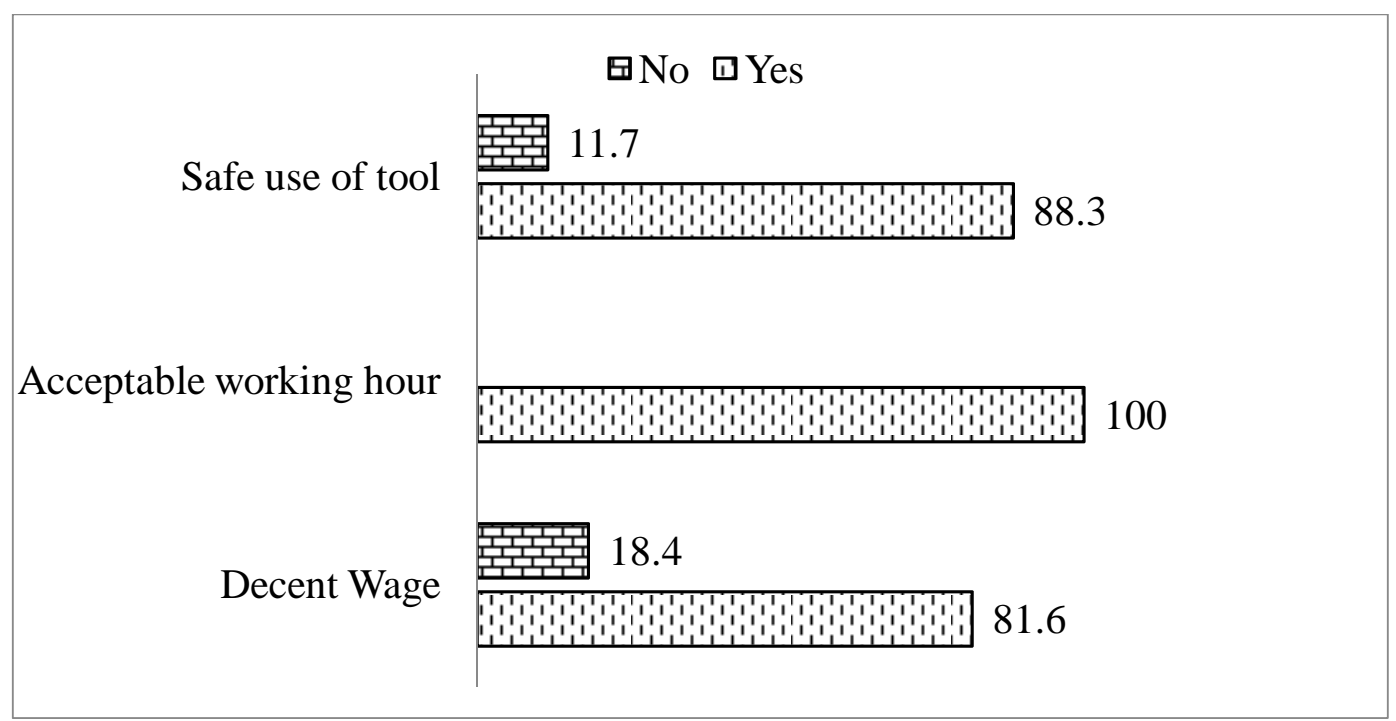

Figure 9. Percentage of farmers adhering to GAP related to human welfare and health and safety

Source: Field survey, 2019

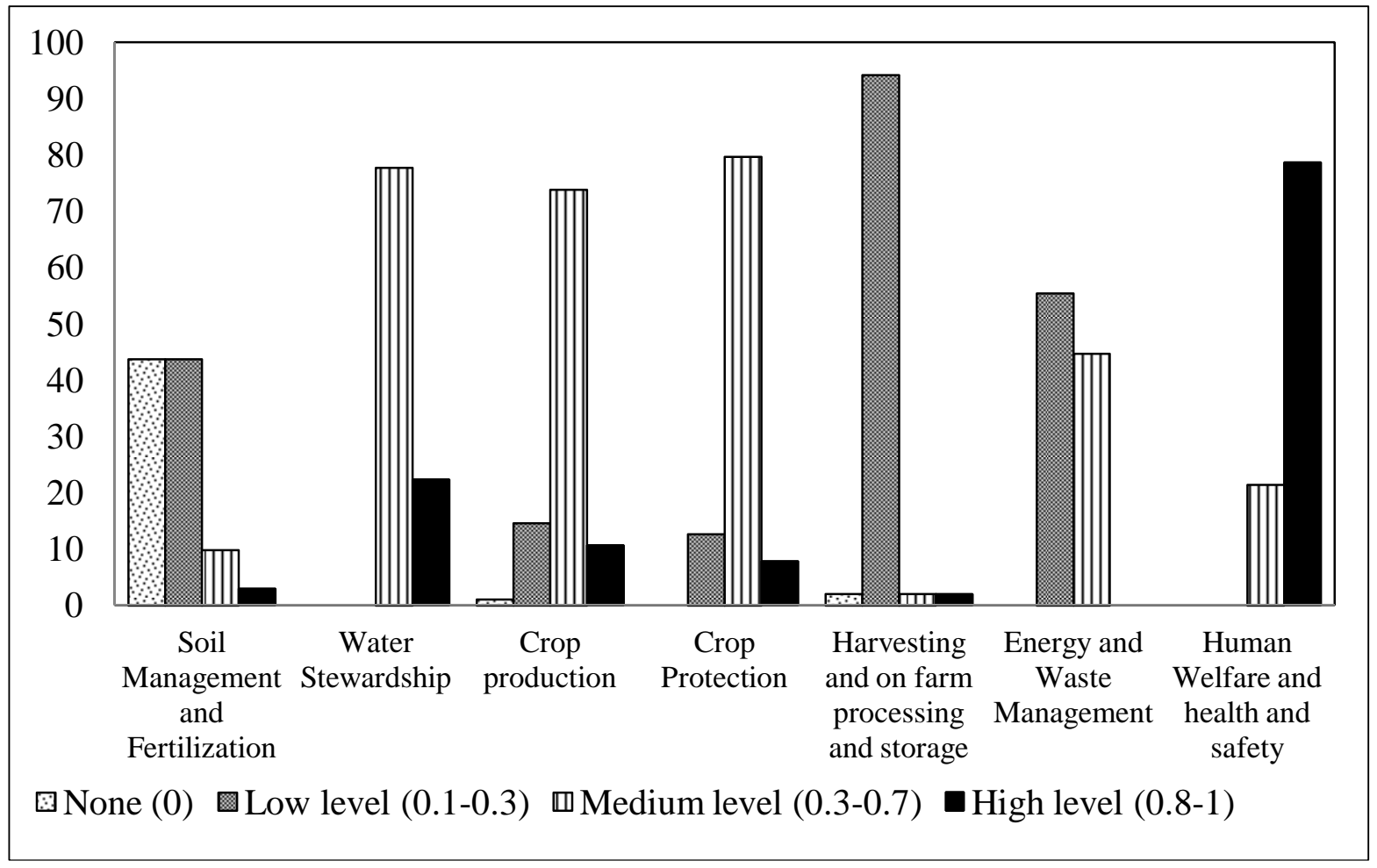

Figure 10. Levels of GAP application by respondent (based on mean of application) Source: Field survey, 2019 